\title{
Uji Stabilitas Warna Hasil Kopigmentasi Asam Tanat dan Asam Sinapat pada Pigmen Brazilin Asal Kayu Secang (Caesalpinia sappan L.) Stability Test of Copigmentation of Brazilin Pigment from Sappan wood (Caesalpinia sappan L.) with Tannic Acid and Sinapic Acid
}

\author{
Yuliasri Ramadhani Meutia*, Irma Susanti*, Nobel Christian Siregar* \\ Balai Besar Industri Agro \\ Jl. Juanda No. 11 Bogor 16122
}

\section{Riwayat Naskah:}

Diterima 03, 2019 Direvisi 05,2019 Disetujui 05,2019

\begin{abstract}
ABSTRAK: Secang merupakan jenis tanaman kayu yang berpotensi untuk digunakan sebagai pewarna alami pada makanan. Salah satu komponen warna dalam secang adalah pigmen brazilin. Salah satu cara untuk menurunkan laju degradasi pigmen brazilin adalah melalui proses kopigmentasi. Penelitian ini bertujuan untuk melihat pengaruh kopigmentasi dengan asam tanat dan asam sinapat terhadap stabilitas warna pigmen brazilin. Pada penelitian ini dilakukan kopigmentasi dengan senyawa kopigmen yaitu asam tanat dan asam sinapat dengan perbandingan $1: 0 ; 1: 1 ; 2: 1$; dan 5:1. Uji stabilitas dilakukan dengan menguji hasil kopigmentasi yang menghasilkan efek bathokromik dan hiperkromik terbaik saat dipanaskan pada suhu $40{ }^{\circ} \mathrm{C}, 50^{\circ} \mathrm{C}, 60^{\circ} \mathrm{C}, 70^{\circ} \mathrm{C}$, dan $80^{\circ} \mathrm{C}$. Parameter stabilitas warna yang diuji adalah laju retensi warna, konstanta laju degradasi (nilai k) dan pengukuran kualitas warna dengan alat kromameter. Hasil pengujian menunjukkan kopigmentasi dengan asam tanat $(5: 1)$ lebih efektif dalam menstabilkan pigmen brazilin dibandingkan dengan kopigmentasi dengan asam sinapat (5:1) melalui hasil uji bathokromik, hiperkromik, retensi warna, konstanta laju degradasi, nilai a, dan nilai ${ }^{\circ}$ hue.
\end{abstract}

Kata kunci: secang, zat warna alami, chromameter

ABSTRACT: The aim of this study is to determine the copigment compound (tannic acid and sinapic acid) that can give the best results on the stability of brazilin extract from sappan wood. Copigmentation is performed on the ratio $(\mathrm{v} / \mathrm{v})$ of 1:0; $1: 1 ; 2: 1$; and 5:1 that observed from the bathochromic effects and the hyperchromic effects of measurements using UV-vis Evolution 201 spectrophotometer. Stability test were performed on the copigmentation results which gave the best bathochromic and hyperchromic effect by heating at $40^{\circ} \mathrm{C}, 50^{\circ} \mathrm{C}, 60^{\circ} \mathrm{C}, 70^{\circ} \mathrm{C}$, and $80{ }^{\circ} \mathrm{C}$. Color stability parameters can be observed from color retention rate, degradation rate constant ( $\mathrm{k}$ value) and color quality by observing the value of red and blue degree (a value) and ${ }^{\circ}$ hue using Chromameter. The results showed that copigmentation using tannic acid was more effective in stabilizing brazilin pigment than using sinapic acid.

Keywords: sappan wood, natural color, chromameter

\footnotetext{
Kontributor utama

Email : yhoely@gmail.com; irma.naura@gmail.com; nobel_7@yahoo.com
} 


\section{Pendahuluan}

Seiring dengan peningkatan permintaan konsumen yang kuat dalam penggunaan produk alami maka terjadi pengembangan pewarna alami baru untuk digunakan di industri makanan di beberapa negara (Wissgott and Bortlik, 1996; Yusuf et al., 2017). Salah satu tanaman yang berpotensi sebagai pewarna makanan alami adalah kayu secang (Caesalpinia sappan L.). Secang banyak mengandung asam galat, brazilin, brazilein, delta- $\alpha$ phellandrene, oscimene, resin, resorsin, minyak atsiri, dan asam tanat, yang terdapat pada batang kayunya. Daun dari tanaman secang mengandung 0,16-0,20\% minyak atsiri (Arief, 2008; Mekala and Radha, 2015). Secang mengandung berbagai komponen fenolik termasuk xanthone, kumarin, chalcones, flavones, homoisoflavonoids, dan brazilin (Nirmal, et al. 2015). Pigmen yang memberi warna merah pada kayu secang berasal dari senyawa brazilin. Mastuti et al. (2012) melaporkan bahwa secang mengandung 10,1 g brazilin/gram kayu kering. Pigmen pada kayu secang sangat dipengaruhi oleh pH. Pada kondisi asam (pH 2-5) brazilin memberikan warna kuning, pada $\mathrm{pH}$ 6-7 menunjukkan warna merah, dan pada situasi basa (pH di atas 8) menunjukkan warna keunguan merah (Adawiyah et al. 2008). Suhu pemanasan, sinar UV, oksidator, reduktor, dan keberadaan logam juga memengaruhi stabilitas dan laju degradasi pigmen brazilin (Maharani, 2003). Salah satu cara yang dapat digunakan untuk mengurangi terjadinya reaksi degradasi ini adalah kopigmentasi. Kopigmentasi dapat diamati dari efek bathokromik ( $\Delta \lambda \max$ ), yang merupakan pergeseran panjang gelombang maksimum dan efek hiperkromik $(\Delta \mathrm{A})$, yang merupakan peningkatan intensitas warna setelah kopigmentasi. Pada antosianin, adanya kopigmentasi menyebabkan perubahan warna dari merah menjadi efek kebiruan. Penambahan kopigmen dapat memengaruhi keefektifan kopigmentasi. Penggunaan rasio kopigmen yang terlalu rendah dapat menyebabkan kopigmentasi menjadi tidak efektif karena ikatan lemah yang terbentuk, sedangkan penggunaan rasio molar yang terlalu tinggi tidak efisien (Boulton, 2001; Zhang et al., 2017).

Berdasarkan penelitian yang dilakukan oleh Wahyuni et al. (2017) tannin kopigmentasi dalam ekstrak antosianin kulit tamarillo (Solanum betaceum) mampu menstabilkan warna ekstrak antosianin selama 40 hari penyimpanan, sedangkan penggunaan asam dapat memberikan peningkatan warna merah selama proses kopigmentasi (Adawiyah et al., 2008). Penelitian lain menunjukkan bahwa warna antosianin apel berdaging merah tergantung pada nilai pH larutan jelas. Properti antosianin tetap stabil dan warnanya tetap merah ketika pH 3.0. Asam kafeat, asam ferulat, asam klorogenat dan asam galat menunjukkan berbagai tingkat efek hiperkromik dan perubahan bathokromik pada antosianin apel berdaging merah dan terbukti meningkatkan stabilitas antosianin (P0.05) dalam berbagai kondisi pemanasan, paparan cahaya, oksidasi dan menambahkan ion logam $\mathrm{Fe} \sim(3+)$ (Fan et al., 2017).

Hanya sedikit penelitian tentang kopigmentasi kayu secang yang telah dilakukan, efek kopigmentasi asam sinapat pada kayu secang dan kestabilan warnanya telah diteliti sebelumnya (Safitri, 2009). Berdasarkan penelitian ini, kopigmentasi optimal adalah brazilein dengan asam sinapat untuk meningkatkan stabilitas warna terhadap pemanasan dan sinar UV adalah dengan rasio konsentrasi brazilein:asam sinapat 1:5. Namun, untuk diterapkan pada minuman komersial, pewarna brazilein dengan kopigmentasi asam sinapat masih kurang baik karena kestabilannya masih sangat rendah. Asam tanat sudah banyak diaplikasikan sebagai senyawa kopigmen pada pewarna antosianin. Susanti et al. (2017) telah mengaplikasikan asam tanat sebagai salah satu senyawa kopigmen pada zat warna ungu dari ubi jalar (Ipomoea batatas L.). Oleh karena itu, perlu dipelajari perbandingan antara asam sinapat dan asam tanat sebagai faktor kopigmen untuk menunjukkan mana yang memberikan hasil terbaik untuk kopigmentasi kayu secang. Hasil kopigmentasi diharapkan dapat meningkatkan stabilitas pigmen brazilin. Peningkatan stabilitas warna dapat dilihat dari penurunan laju degradasi pigmen brazilin yang ditunjukkan oleh peningkatan waktu paruh sehingga stabilitas hasil kopigmentasi pada berbagai suhu pemanasan dapat diukur.

\section{Bahan dan Metode}

\subsection{Bahan}

Bahan yang digunakan pada penelitian ini adalah kayu secang (Caesalpinia sappan L.) yang diperoleh dari Pasar Beringharjo Yogyakarta, $\mathrm{NaHCO}_{3}$ untuk pengatur keasaman, asam tanat, asam sinapat, ammonium asetat, dimetil sulfoksida (DMSO), standar brazilin, dan bahan kimia lainnya untuk analisis.

\subsection{Alat}

Alat yang digunakan pada penelitian ini antara lain hammer mill, concentration boule, freeze dryer (Martin Christ), kromameter (Minolta CR-400), spectrophotometer porselen (UV-Vis Evolution 
Citation: Meutia, Y. R, Susanti, I., Siregar, N. C (2019) Uji Stabilitas Warna Hasil Kopigmentasi Asam Tanat dan Asam Sinapat pada Pigmen Brazilin Asal Kayu Secang (Caesalpinia sappan L.) Warta IHP, 36(1), 30-39

Halaman | 32

201), oven (Memmert), desikator, dan penangas air (Buchi).

\subsection{Metode Penelitian}

\subsubsection{Ekstraksi Pigmen Brazilin Asal Secang}

Kayu secang dihancurkan dengan hammer mill untuk mereduksi ukurannya. Proses ekstraksi dilakukan dengan menggunakan air bersuhu $98{ }^{\circ} \mathrm{C}$ selama 100 menit dengan rasio secang dan air 1:10. Proses ekstraksi dilakukan dalam kondisi basa dengan menambahkan $\mathrm{NaHCO}_{3}$ pada air hingga mencapai $\mathrm{pH}$ 9. Filtrat yang diperoleh disaring dengan kain saring untuk memperoleh ekstrak cair. Kemudian dilakukan pemekatan menggunakan concentration boule hingga diperoleh ekstrak pekat. Ekstrak pekat kemudian di kering bekukan dengan freeze dryer untuk menjaga kualitas dan stabilitas ekstrak.

\subsubsection{Kopigmentasi dan Uji Stabilitas Pigmen Brazilin}

Proses kopigmentasi dari ekstrak pigmen brazilin asal secang dilakukan menggunakan asam sinapat dan asam tanat. Selanjutnya dilakukan uji stabilitas terhadap hasil kopigmentasi. Sediaan kopigmen diperoleh dengan cara mencampurkan masing-masing 0,154 gram ammonium asetat yang telah dilarutkan dalam $100 \mathrm{ml}$ akuades dengan 3,402 gram untuk asam tanat dan 0,448 gram untuk asam sinapat yang sebelumnya telah dilarutkan masing-masing dalam $10 \mathrm{ml}$ DMSO. Ekstrak brazilin hasil freeze dry sebanyak 2,46 gram dilarutkan dalam akuades dengan konsentrasi 0,02 M. Apabila sampel terlalu pekat, maka dapat dilakukan pengenceran. Larutan brazilin yang diperoleh direaksikan dengan sediaan kopigmen dengan perbandingan $(\mathrm{v} / \mathrm{v})$ 1:0, 1:1, 2:1 dan 5:1. Efek bathokromik dan efek hiperkromik dari pengkopigmentasian pigmen brazilin ekstrak kayu secang dengan senyawa asam sinapat dan juga asam tanat diamati dari nilai panjang gelombang maksimum dan nilai absorbansi yang diukur dengan menggunakan spektrofotometer UV-Vis Evolution 201.

Pengujian stabilitas dilakukan terhadap hasil kopigmentasi pigmen brazilin dengan kopigmen asam sinapat dan asam tanat yang terhadap absorbansi dengan menggunakan spektrofotometer UV-Vis dan pengukuran kualitas warna dengan menggunakan warna, konstanta laju degradasi (nilai k) dan waktu paruh (t1/2). Pengukuran stabilitas dilakukan setiap 75 menit untuk suhu 40 ${ }^{\circ} \mathrm{C}, 60$ menit untuk suhu $50{ }^{\circ} \mathrm{C}, 45$ menit untuk suhu $60{ }^{\circ} \mathrm{C}$, 30 menit untuk suhu $70{ }^{\circ} \mathrm{C}$ dan 15 menit untuk suhu $80{ }^{\circ} \mathrm{C}$. Pengukuran parameter perbedaan kooordinat warna dilakukan menggunakan Chromameter dengan memperhatikan parameter L, a, b. Parameter pengukuran stabilitas warna dapat diamati dari nilai retensi memberikan efek bathorokromik dan hiperkromik terbaik. Sampel dengan hasil kopigmentasi terbaik dimasukkan ke dalam botol gelap dan dipanaskan dalam waterbath dengan variasi suhu $40{ }^{\circ} \mathrm{C}, 50{ }^{\circ} \mathrm{C}, 60{ }^{\circ} \mathrm{C}, 70{ }^{\circ} \mathrm{C}$, dan $80{ }^{\circ} \mathrm{C}$. Selanjutnya dilakukan pengamatan pada suhu-suhu tersebut.

\subsubsection{Uji Kualitas Warna dengan Metode Kromameter}

Pengukuran warna dilakukan terhadap larutan brazilin hasil kopigmentasi dengan asam sinapat dan asam tanat yang tidak dipanaskan dan yang telah dipanaskan dengan menggunakan Minolta Chromameter CR-400. Data pengukuran yang diperoleh dapat berupa nilai absolut maupun nilai selisih dengan warna standar. Sistem warna Hunter Lab memiliki tiga atribut yaitu L, a, dan b. Nilai L menunjukkan kecerahan sampel dengan nilai dari 0 sampai 100. Nilai a menunjukkan derajat merah $(\mathrm{a}+)$ atau hijau (a-) hijau dengan skala nilai dari -80 sampai 100. Nilai b menunjukkan derajat kuning $(b+)$ atau biru (b-) dengan skala nilai dari -70 sampai 70. Sebelum chromameter digunakan dilakukan kalibrasi menggunakan plat putih dengan nilai $\mathrm{Y}=92,89, \mathrm{x}=0.3178$, dan $\mathrm{y}=0.3338$.

\section{Hasil dan Pembahasan}

\subsection{Ekstraksi Brazilin}

Pigmen brazilin yang merupakan zat warna yang terdapat pada kayu secang diperoleh dengan cara ekstraksi. Ekstraksi merupakan suatu proses memisahkan atau menarik satu atau lebih komponen atau senyawa-senyawa dari suatu sampel dengan menggunakan pelarut tertentu yang sesuai (Leba, 2017). Sebelum proses ekstraksi, bahan baku potongan kayu secang dihaluskan terlebih dahulu dengan tujuan untuk memperbesar luas permukaan dari kayu secang tersebut sehingga meningkatkan proses ekstraksi ke dalam pelarut. Proses ekstraksi brazilin dilakukan dengan cara perebusan menggunakan pelarut air. Pemilihan pelarut merupakan salah satu faktor penting dalam proses ekstraksi. Brazilin yang merupakan golongan flavonoid dapat diekstraksi dengan menggunakan pelarut etanol, metanol maupun air. Berdasarkan penelitian-penelitian yang telah dilakukan sebelumnya, pelarut metanol lebih efektif dibandingkan dengan pelarut etanol, akan tetapi dikarenakan sifat toksik yang dimiliki oleh metanol 
dan etanol maka penggunaan air menjadi pilihan terbaik dalam proses ekstraksi kayu secang.

Senyawa brazilin yang terdapat pada kayu secang memiliki kepolaran yang tinggi sehingga dapat larut dalam air karena sama-sama polar. Air merupakan pelarut yang bersifat polar dimana mampu mengekstrak senyawa yang memiliki kepolaran rendah hingga tinggi. Proses ekstraksi dilakukan dalam suasana basa yaitu dengan menambahkan $\mathrm{NaHCO}_{3}$ sehingga diperoleh ekstrak berwarna merah keunguan. Pigmen brazilin pada pH 2-5 berwarna kuning, pH 6-7 berwarna merah, dan pada pH 8 ke atas berwarna merah keunguan (Adawiyah et al., 2008). Larutan ekstrak brazilin dikering-bekukan dengan menggunakan freeze dryer dengan tujuan untuk memisahkan hampir sebagian besar air dalam bahan yang terjadi melalui mekanisme sublimasi. Kelebihan dari pengeringan beku dibanding pengeringan biasa adalah dapat mempertahankan stabilitas atau mutu produk dimana tidak menyebabkan permukaan yang keriput, lebih porus (mudah dilalui air), mudah disegarkan kembali, warna normal, nilai flavor dan mutu gizi lebih dapat dipertahankan (Haryadi, 2013). Ekstrak yang dikeringkan dalam freeze dryer sebelumnya telah dipekatkan menggunakan reaktor untuk mempercepat proses pengeringan.
Berdasarkan penelitian yang dilakukan oleh Hernani et al., (2017), yaitu ekstraksi kayu secang dengan menggunakan berbagai pelarut diperoleh rendemen sebesar $16,06 \%$ dari pelarut metanol yang diasamkan dan 10,76\% dari pelarut etanol dengan ekstraksi metode maserasi selama 24 jam. Sedangkan ekstraksi dengan menggunakan pelarut air dengan cara pemanasan pada suhu $100^{\circ} \mathrm{C}$ sampai volume air menjadi sepertiganya diperoleh rendemen sebesar 23\%. Pada penelitian ini diperoleh hasil rendemen ekstrak kayu secang sebesar 12,3\%. Rendemen menyatakan kuantitas atau banyaknya ekstrak yang dihasilkan dari proses ekstraksi suatu tanaman.

\subsection{Kopigmentasi Brazilin dengan Asam Tanat dan Asam Sinapat}

Kopigmentasi bertujuan untuk meningkatkan kestabilan dari suatu zat warna alami. Pada penelitian ini pigmen brazilin dikopigmentasi dengan asam sinapat dan asam tanat dengan perbandingan 1:0, 1:1, 2:1 dan 5:1. Penampakan hasil kopigmentasi brazilin dengan asam sinapat dan asam tanat dapat dilihat pada Gambar 1.
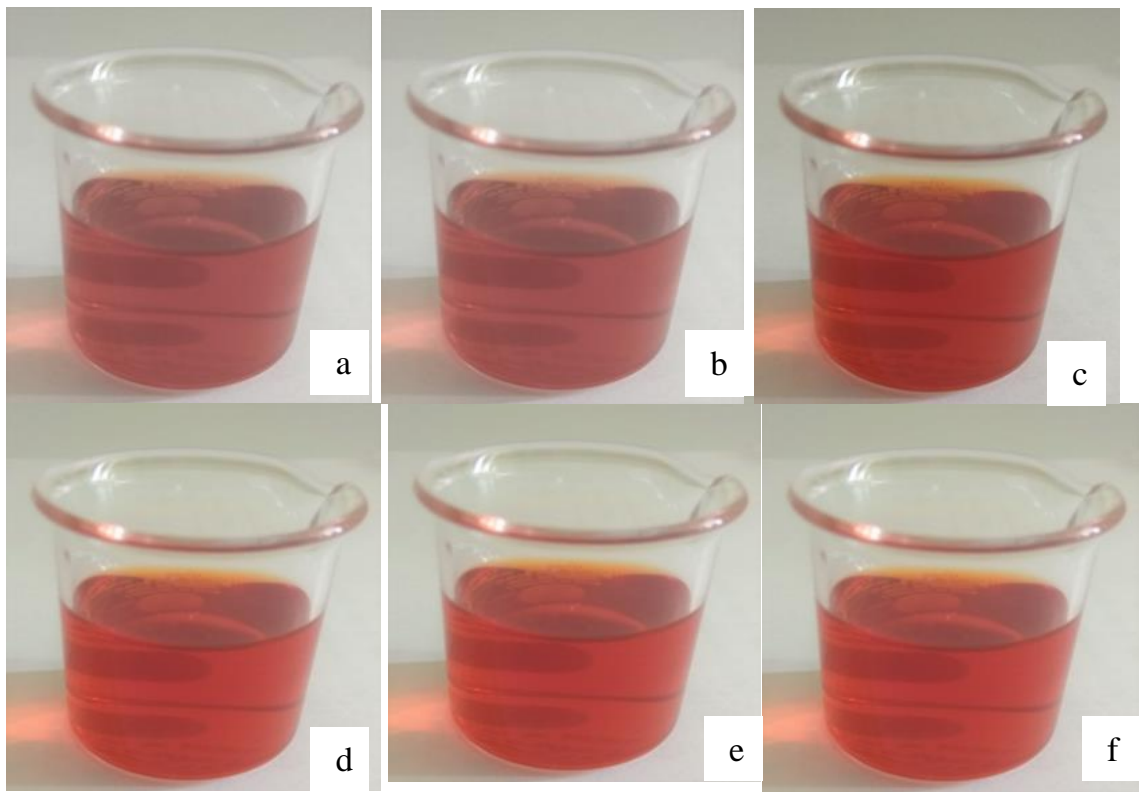

Gambar 1. Kopigmentasi pigmen brazilin dengan asam sinapat dengan perbandingan 1:1 (a); $2: 1$ (b); 5:1 (c) dan dengan asam tanat dengan perbandingan 1:1 (d); 2:1 (e); 5:1 (f).

Gambar 1 menunjukkan bahwa kopigmentasi dengan asam sinapat pada perbandingan 1:1 dan 2:1 memiliki warna yang berbeda dengan kopigmentasi pada perbandingan 5:1. Sedangkan kopigmentasi dengan asam tanat pada perbandingan 1:1, 2:1 dan 5:1 memiliki warna yang sama yaitu merah keorangean. Berdasarkan efek bathokromik dan hiperkromik serta penampakan warna secara visual, uji kestabilan terhadap pemanasan pada kopigmentasi dengan asam sinapat dilakukan pada perbandingan 5:1. Sedangkan untuk kopigmentasi dengan asam tanat uji kestabilan dapat dilakukan pada perbandingan $1: 1,2: 1$ maupun pada perbandingan 5:1. Akan 
tetapi pada penelitian ini uji kestabilan terhadap pemanasan pada kopigmentasi dengan asam tanat dilakukan pada perbandingan 5:1 dikarenakan secara visual warna yang dihasilkan tidak berbeda dengan warna hasil kopigmentasi pada perbandingan 1:1 dan 2:1. Kopigmentasi dengan menggunakan asam sinapat pada perbandingan 5:1 memberikan pengaruh pergeseran panjang gelombang maksimum $0,414 \mathrm{~nm}$ dan hiperkromik 1,028. Kopigmentasi dengan asam tanat memberikan pengaruh terhadap bathokromik 14,525 nm dan hiperkromik 1,723. Hal ini menunjukkan bahwa efek bathokromik yang dihasilkan dari penggunaan asam sinapat sangat kecil dibandingkan dengan kopigmentasi dengan asam tanat. Sedangkan efek hiperkromik yang diberikan keduanya tidak memberikan perbedaan yang sangat signifikan. Hal ini dapat disebabkan karena adanya subtituen atau auksokrom tertentu pada kromofor. Berdasarkan strukturnya, asam tanat memiliki jumlah $\mathrm{OH}$ (hidroksil) yang lebih banyak jika dibandingkan dengan asam sinapat. Hidroksil merupakan subtituen yang dapat memengaruhi perubahan absorbsi panjang gelombang ke arah panjang gelombang yang lebih besar. Semakin banyak subtituen pada sebuah senyawa maka semakin besar pengaruh yang ditimbulkannya (Suhartati, 2017).

Senyawa asam sinapat dan asam tanat dilarutkan dalam DMSO (dimetilsulfoksida) dengan tujuan untuk mempercepat proses pelarutan dari senyawa tersebut. Pelarut DMSO merupakan pelarut organik dan tidak bersifat bakterisidal (Jacob et al., 2015). Selain itu, pelarut yang dapat melarutkan hampir semua senyawa polar maupun non polar adalah DMSO. Hasil perlakuan kopigmen terhadap pigmen brazilin dapat dilihat pada Tabel 1.

Data yang diperoleh pada Tabel 1 menunjukkan bahwa penggunaan asam sinapat dan asam tanat terhadap kopigmentasi pigmen brazilin memberikan pengaruh efek bathokromik dan hiperkromik yang berbeda. Efek bathokromik (pergeseran panjang gelombang maksimum) dan efek hiperkromik (peningkatan intensitas warna) yang dapat diamati dari peningkatan absorbansi merupakan efek yang dapat menentukan berhasil tidaknya suatu proses kopigmentasi. Efek bathokromik pada asam sinapat terlihat pada perbandingan $5: 1$, sedangkan pada perbandingan 1:1 dan 2:1 terjadi efek hipokromik. Pergeseran panjang gelombang maksimum (efek bathokromik) pada senyawa asam tanat sudah terlihat dari perbandingan 1:1 sampai 5:1. Pengaruh terhadap absorbansi (efek hiperkromik) pada penggunaan senyawa asam sinapat dan asam tanat terjadi pada semua perlakuan. Berdasarkan hasil tersebut, maka perbandingan yang memberikan hasil terbaik dilihat dari efek bathokromik dan efek hiperkromik adalah perbandingan 5:1 untuk senyawa asam tanat dan asam sinapat sehingga pada pengujian stabilitas terhadap pemanasan digunakan perbandingan 5:1.

Kopigmentasi dengan menggunakan asam sinapat pada perbandingan 5:1 memberikan pengaruh ergeseran panjang gelombang maksimum $0,414 \mathrm{~nm}$ dan hiperkromik 1,028. Kopigmentasi dengan asam tanat memberikan pengaruh terhadap bathokromik 14,525 nm dan hiperkromik 1,723. Hal ini menunjukkan bahwa efek bathokromik yang dihasilkan dari penggunaan asam sinapat sangat kecil dibandingkan dengan kopigmentasi dengan asam tanat. Sedangkan efek hiperkromik yang diberikan keduanya tidak memberikan perbedaan yang sangat signifikan.

\subsection{Uji Stabilitas terhadap Pemanasan}

Pemanasan bertujuan untuk mengetahui tingkat stabilitas dari pigmen brazilin. Pengujian stabilitas terhadap pigmen brazilin ekstrak kayu secang dilakukan terhadap kopigmentasi dengan perbandingan 5:1. Pemanasan dilakukan dengan menggunakan waterbath dikarenakan selain berfungsi sebagai pemanas juga berfungsi untuk menghomogenkan suatu larutan dan dapat menjaga kestabilan suatu bahan pada suhu tertentu. Larutan hasil kopigmentasi dengan perbandingan 5:1 dipanaskan dalam botol gelap pada berbagai variasi suhu yaitu suhu $40{ }^{\circ} \mathrm{C}, 50^{\circ} \mathrm{C}, 60^{\circ} \mathrm{C}, 70^{\circ} \mathrm{C}$, dan $80^{\circ} \mathrm{C}$. Pengamatan absorbansi sampel dilakukan dengan menggunakan spektrofotometer UV-Vis Evolution 201 pada panjang gelombang maksimum campuran (kopigmentasi) yang merupakan hasil scanning dengan spektrofotometer. Sedangkan pengamatan kualitas warna diamati dari parameter $\mathrm{L}, \mathrm{a}, \mathrm{b}, \Delta \mathrm{E}$, dan ${ }^{\circ}$ hue dengan menggunakan kromameter Konica Minolta 401.

Pengukuran stabilitas dilakukan dengan mengamati nilai retensi warna dan nilai konstanta laju degradasi (k). Nilai retensi warna merupakan nilai yang dihitung berdasarkan perbandingan absorbansi dari sampel yang telah dipanaskan pada suhu dan waktu tertentu dengan absorbansi sampel sebelum dipanaskan yang dapat didefinisikan dengan rumus At/A0. Pada penelitian ini, absorbansi pigmen brazilin tanpa kopigmentasi adalah 2,630 sedangkan setelah dikopigmentasi dengan asam sinapat nilai absorbansi pigmen brazilin 3,854 dan 4,205 dengan kopigmentasi menggunakan asam tanat. Hal tersebut menggambarkan adanya kopigmentasi dapat meningkatkan absorbansi dari pigmen brazilin. Nilai retensi warna dari pigmen brazilin yang dikopigmentasi dengan asam sinapat dan asam tanat digambarkan dengan hubungan waktu 
Citation: Meutia, Y. R, Susanti, I., Siregar, N. C (2019) Uji Stabilitas Warna Hasil Kopigmentasi Asam Tanat dan Asam Sinapat pada Pigmen Brazilin Asal Kayu Secang (Caesalpinia sappan L.) Warta IHP, 36(1), 30-39

Halaman | 35

Tabel 1.

Hasil kopigmentasi pigmen brazilin dengan asam sinapat dan asam tanat

\begin{tabular}{|c|c|c|c|c|c|c|}
\hline No & Jenis kopigmen & $\begin{array}{c}\text { Perbandingan } \\
(v / v)\end{array}$ & $\lambda_{\text {maks }}(\mathrm{nm})$ & $\overline{\Delta \lambda_{\text {maks }}}$ & Absorbansi & $\Delta_{\text {absorbansi }}$ \\
\hline 1. & Tanpa kopigmen & $1: 0$ & 445 & 0 & 2,630 & 0 \\
\hline 2. & Asam sinapat & $1: 1$ & 361,656 & 83,344 & 4,086 & 1,456 \\
\hline 3. & Asam sinapat & $2: 1$ & 304,047 & 140,953 & 4,500 & 1,87 \\
\hline 4. & Asam sinapat & $5: 1$ & 445,414 & 0,414 & 3,658 & 1,028 \\
\hline 5. & Asam tanat & $1: 1$ & 448,580 & 3,58 & 2,666 & 0,036 \\
\hline 6. & Asam tanat & $2: 1$ & 454,751 & 9,751 & 3,502 & 0,872 \\
\hline 7. & Asam tanat & $5: 1$ & 459,525 & 14,525 & 4,353 & 1,723 \\
\hline
\end{tabular}
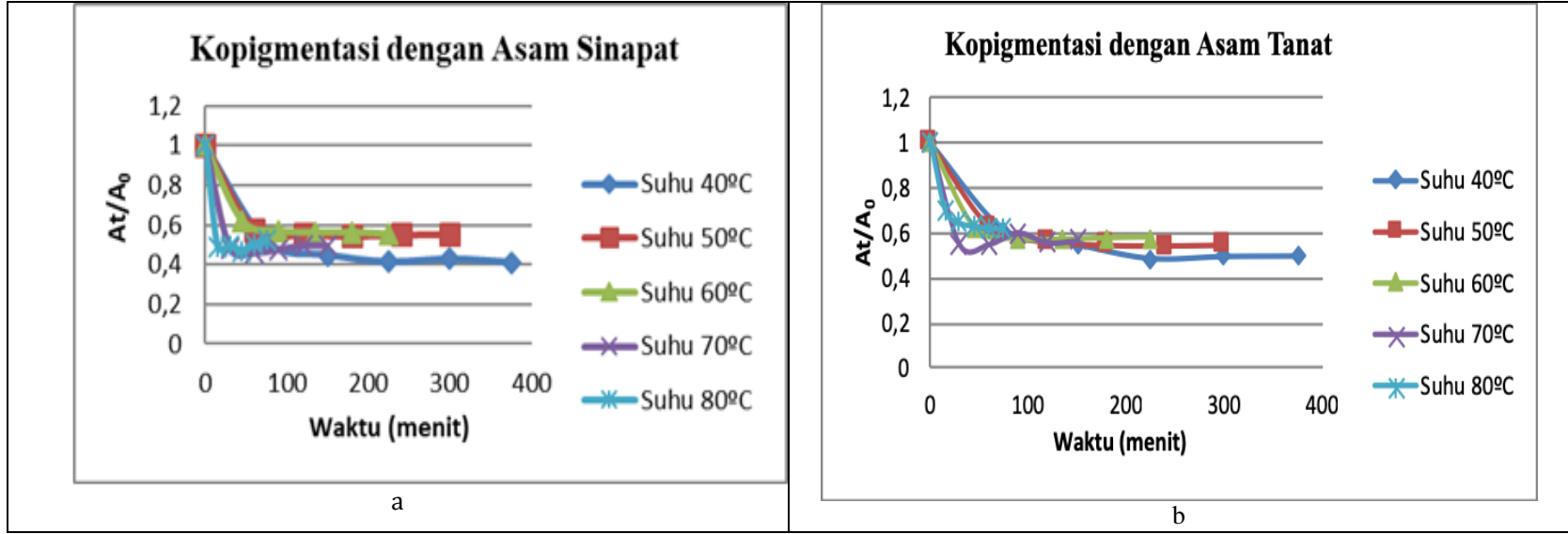

Gambar 2. Grafik Hubungan At/Ao terhadap Waktu dengan Kopigmentasi Asam Sinapat (a) dan Asam Tanat (b)

Tabel 2.

Nilai k kopigmentasi pigmen brazilin pada berbagai suhu

\begin{tabular}{ccc}
\hline Suhu $\left({ }^{\circ} \mathbf{C}\right)$ & Kopigmentasi dengan Asam Sinapat & Kopigmentasi dengan Asam Tanat \\
\hline 40 & $3,87 \times 10^{-3}$ & $3 \times 10^{-3}$ \\
50 & $3,96 \times 10^{-3}$ & $3,43 \times 10^{-3}$ \\
60 & $4,5 \times 10^{-3}$ & $4,41 \times 10^{-3}$ \\
70 & $9,32 \times 10^{-3}$ & $7,17 \times 10^{-3}$ \\
80 & 0,017 & 0,01019 \\
\hline
\end{tabular}

pemanasan pada suhu tertentu dengan nilai At/A0 yang dapat dilihat pada Gambar 2.

Berdasarkan grafik tersebut, secara umum nilai retensi warna pigmen brazilin yang dikopigmentasi dengan asam sinapat dan asam tanat pada berbagai suhu cenderung turun sejak awal pemanasan yang mengindikasikan bahwa pigmen brazilin mengalami degradasi. Penambahan asam tanat cenderung lebih dapat menurunkan degradasi dari pigmen brazilin dibandingkan dengan kopigmentasi dengan asam sinapat. Hal ini ditunjukkan dengan nilai retensi warna asam tanat yang lebih besar.

Parameter lain yang diamati dari pengukuran stabilitas warna kopigmentasi pigmen brazilin adalah nilai konstanta laju degradasi (nilai k) dan waktu paruh (t1/2). Nilai $\mathrm{k}$ dapat diperoleh dari dari hubungan antara In At/Ao dengan waktu. Secara teori semakin tinggi nilai $\mathrm{k}$ maka laju degradasi pigmen brazilin semakin meningkat. Pada penelitian ini laju degradasi pigmen brazilin mengikuti kinetika reaksi ordo satu. Kebanyakan dari beberapa penelitian mengenai kinetika degradasi termal komponen bioaktif seperti antosianin, karotenoid, likopen, dan sebagainya mengikuti kinetika reaksi orde ke satu. Hal ini diperkuat dengan penelitian yang dilakukan oleh Safitri (2009) tentang kopigmentasi brazilein terhadap stabilitas model minuman dan Kopjar et al., (2009) tentang kopigmentasi antosianin terhadap stabilitas jus red currant.

Berdasarkan nilai $\mathrm{k}$ pada Tabel $6 \mathrm{di}$ atas menunjukkan bahwa semakin tinggi suhu, nilai $\mathrm{k}$ semakin besar. Hal ini menandakan bahwa pada pemanasan dengan suhu yang tinggi pigmen brazilin semakin tidak stabil. Kopigmentasi dengan asam sinapat memberikan nilai $\mathrm{k}$ yang lebih besar jika dibandingkan dengan kopigmentasi dengan asam tanat. Penggunaan asam tanat lebih dapat melindungi brazilin dari reaksi degradasi akibat pemanasan. Penelitian serupa pada kopigmentasi antosianin dari ekstrak anggur Cabernet Sauvignon oleh beberapa senyawa asam organik (asam kafeat, asam ferulat, asam galat, dan asam tanat) 
Citation: Meutia, Y. R, Susanti, I., Siregar, N. C (2019) Uji Stabilitas Warna Hasil Kopigmentasi Asam Tanat dan Asam Sinapat pada Pigmen Brazilin Asal Kayu Secang (Caesalpinia sappan L.) Warta IHP, 36(1), 30-39

Halaman | 36

menunjukkan bahwa asam tanat menunjukkan efek perlindungan terbaik dengan waktu paruh 2,585 jam (Gauche et al. 2010).

\subsection{Pengukuran dengan Kromameter}

Pengukuran kualitas warna dengan menggunakan kromameter akan diperoleh nilai $\mathrm{L}$, a, dan b. Pada penelitian ini digunakan Konica Minolta Chromameter CR-410. Nilai L menunjukkan kecerahan atau gelap dan terangnya suatu sampel. Nilai L memiliki nilai dari 0 sampai 100. Semakin besar nilai L maka semakin cerah warna suatu sampel. Nilai a memiliki nilai dari -80 sampai 100 yang menunjukkan derajat warna merah $(\mathrm{a}+)$ dan hijau (a-). Sedangkan nilai b memiliki nilai dari -70 sampai 70 yang menyatakan derajat warna kuning $(b+)$ dan biru (b-)

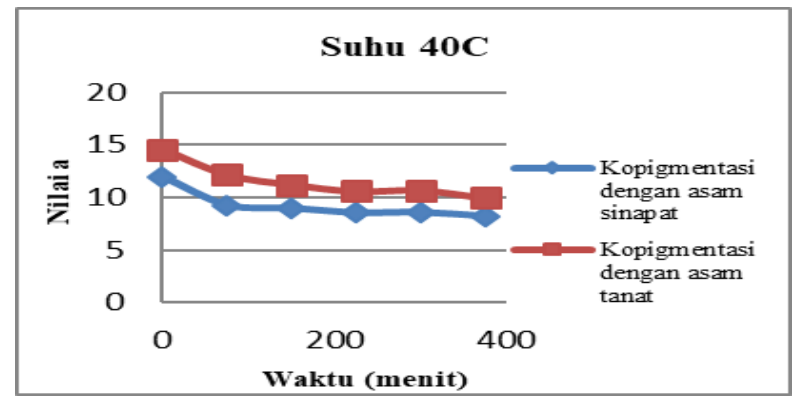

a

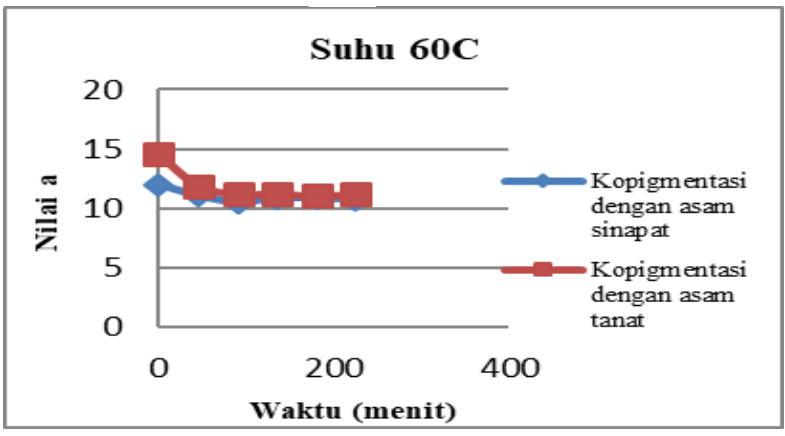

Pengamatan stabilitas warna kopigmentasi pigmen brazilin dengan asam sinapat dan asam tanat dengan kromameter dilakukan pada berbagai variasi suhu dan waktu. Berdasarkan data yang diperoleh nilai L secara umum cenderung naik dengan semakin meningkatnya suhu dan lamanya waktu pemanasan. Kenaikan nilai L menandakan bahwa warna sampel semakin pudar. Parameter lain dari pengukuran kualitas warna dengan kromameter adalah nilai a yang menyatakan derajat warna merah $(\mathrm{a}+)$ dan hijau (a-). Nilai a yang dihasilkan dari hasil kopigmentasi sebelum dipanaskan lebih tinggi. Seiring dengan waktu pemanasan, nilai a semakin menurun. Semakin rendah nilai a maka derajat warna merah semakin rendah sedangkan derajat warna hijau semakin tinggi. Perbandingan nilai a kopigmentasi dengan asam sinapat dan asam tanat pada berbagai suhu dapat dilihat pada Gambar 3.

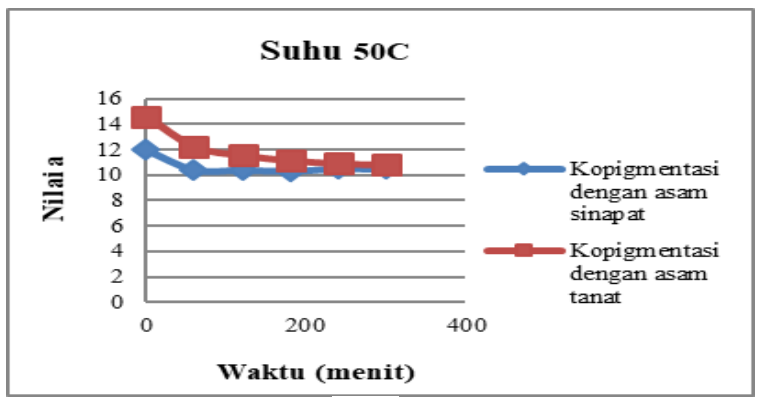

b

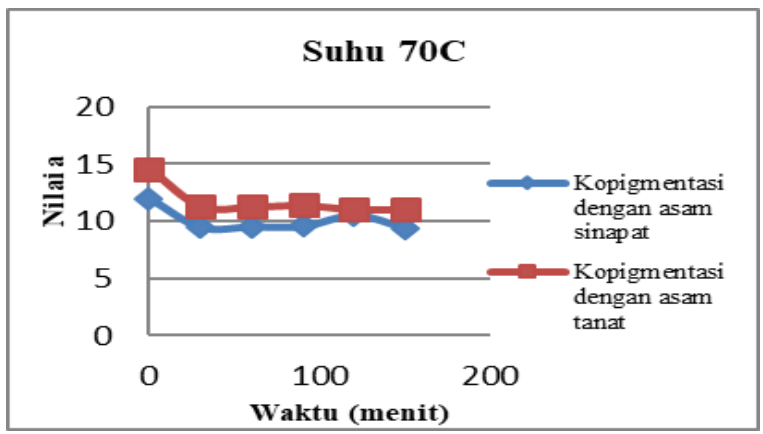

Suhu 80C

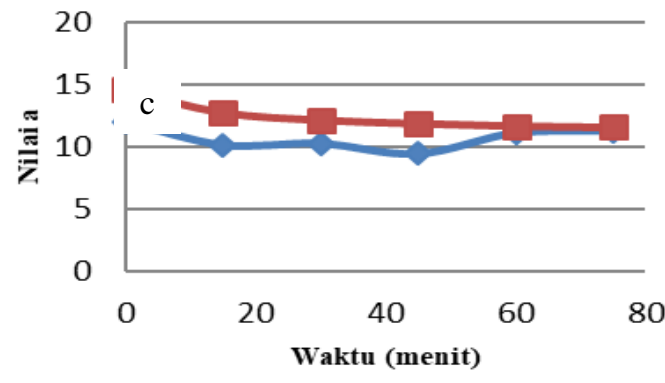

d

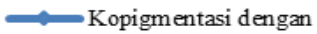
asam sinapat

- Kopigmentasi dengan asam tanat

Gambar 3. Grafik antara nilai a dengan waktu pada berbagai suhu dengan kopigmentasi asam sinapat dan asam tanat. Pemanasan suhu $40{ }^{\circ} \mathrm{C}(\mathrm{a}) ; 50^{\circ} \mathrm{C}(\mathrm{b}) ; 60^{\circ} \mathrm{C}(\mathrm{c}) ; 70^{\circ} \mathrm{C}(\mathrm{d}) ; \operatorname{dan} 80^{\circ} \mathrm{C}(\mathrm{e})$. 
Nilai a sebelum proses pemanasan adalah 12,00 untuk kopigmentasi dengan asam sinapat dan 14,58 untuk kopigmentasi dengan asam tanat. Menurunnya nilai a disebabkan karena terjadinya degradasi dari pigmen brazilin akibat pemanasan. Nilai a dengan kopigmentasi menggunakan asam tanat mengalami penurunan yang lebih kecil dibanding dengan kopigmentasi menggunakan asam sinapat. Selain nilai a, nilai b yang merupakan parameter yang menyatakan derajat warna kuning $(b+)$ dan biru (b-) juga memberikan pengaruh terhadap stabilitas dari kopigmentasi pigmen brazilin. Pemanasan menyebabkan nilai b semakin meningkat. Naiknya nilai b dapat disebabkan karena terbentuknya komponen hasil degradasi brazilin warna kuning. Selain itu juga dapat disebabkan karena reaksi kopigmentasi brazilin dengan kopigmen yang digunakan menggeser nilai merah menjadi warna kuning (bathokromik).

Pengamatan warna selain memperhatikan nilai $\mathrm{L}$, a, dan $\mathrm{b}$ juga dapat dilakukan dengan mengolah data $\mathrm{L}$, a, dan b menjadi nilai $\Delta \mathrm{E}$ dan ${ }^{\circ}$ hue. Nilai $\Delta \mathrm{E}$

menggambarkan perubahan warna secara keseluruhan yang dihitung dengan rumus $\sqrt{(\Delta \boldsymbol{L})^{2}+(\Delta \boldsymbol{a})^{2}+(\Delta \boldsymbol{b})^{2}}$. Peningkatan waktu

pemanasan dapat meningkatkan nilai $\Delta \mathrm{E}$ akibat perubahan nilai $L$, a, dan b. Secara umum dengan meningkatnya suhu dan lamanya pemanasan nilai $\Delta \mathrm{E}$ cenderung semakin meningkat. Sedangkan nilai 'hue adalah nilai yang menggambarkan kisaran warna suatu sampel sampel. Nilai ${ }^{\circ}$ hue dihitung dengan menghitung invers tangen perbandingan nilai $b$ dan a sehingga diperoleh sudut dari diagram warna. Berdasarkan nilai 'hue pada lampiran menunjukkan bahwa semakin lamanya waktu pemanasan maka nilai ${ }^{\circ}$ hue akan semakin meningkat.

Nilai 'hue pada kopigmentasi dengan asam sinapat sebelum proses pemanasan adalah 57,08. Berdasarkan interpretasi warna hue pada peta warna kromasitas Munsell nilai ${ }^{\circ}$ hue 57,08 berada pada daerah kisaran warna merah kuning. Daerah kisaran warna merah kuning memiliki nilai ${ }^{\circ}$ hue dari $54^{\circ}-90^{\circ}$. Proses pemanasan pada berbagai suhu tidak menyebabkan terjadinya pergeseran warna merah kuning ke daerah kisaran warna lain. Kopigmentasi dengan menggunakan asam sinapat tetap berwarna merah kuning hingga akhir pemanasan. Kopigmentasi dengan menggunakan asam tanat memiliki nilai ${ }^{\circ}$ hue 48,76 sebelum dilakukan proses pemanasan. Nilai ${ }^{\circ}$ hue 48,76 berada pada daerah kisaran warna merah. Daerah kisaran warna merah memiliki nilai ${ }^{\circ}$ hue dari $18^{\circ}$ $54^{\circ}$. Setelah pemanasan kopigmentasi dengan asam tanat mengalami pergeseran warna dari merah ke merah kuning hingga akhir proses pemanasan.

Nilai ${ }^{\circ}$ hue menyatakan warna visual yang dilihat pada setiap derajat tertentu yang diubah ke dalam kisaran warna hue yang mendekati kisaran warna yang sebenarnya. Pergeseran warna yang terjadi dapat disebabkan oleh penumpukan hasil degradasi kopigmentasi pigmen brazilin dengan asam sinapat dan asam tanat.

\section{Kesimpulan}

Berdasarkan hasil penelitian ini, kopigmentasi menggunakan asam tanat lebih efektif dalam menstabilkan warna pigmen brazilin dibandingkan dengan asam sinapat. Hal ini dapat dilihat dari efek bathokromik, hiperkromik, retensi warna, konstanta laju degradasi, waktu paruh, nilai a, dan nilai ${ }^{\circ}$ hue yang diukur menggunakan chromameter.

\section{Ucapan terima kasih}

Dengan telah terlaksananya penelitian ini, maka tim mengucapkan terimakasih kepada Balai Besar Industri Agro sebagai kegiatan penelitian DIPA BBIA. Dan tak lupa pula diucapkan terima kasih kepada Enrica Asrinawati Waruwu yang banyak membantu dalam pelaksanaan penelitian ini.

\section{Daftar Pustaka}

Adawiyah, D.R., Lioe, H.N., Faridah, D.N., Kristie, A., dan Weningtas, H. (2008). Laporan Akhir Tahun Kopigmentasi Brazilein Kayu Secang (Caesalpinia sappan L.) dalam Upaya Meningkatkan Spektrum Stabilitas sebagai Pewarna Alami untuk Produk Pangan. Lembaga Penelitian dan Pengabdian kepada Masyarakat. Institut Pertanian Bogor.

Arief, H. (2008). Tumbuhan Obat dan Khasiatnya. Penebar Swadaya Grup.

Boulton, R. (2001). The copigmentation of anthocyanins and its role in the color of red wine: a critical review. Journal Etnology and Viticulture. Vol. 52(2): 67-84.

Fan, S., Jia, X.,.Xi, Y., Hong, D., Yonghong, M., and Yurong, G. (2017). Effects of phenolic acids on copigmentation and stability of anthocyanins in red-fleshed apple. Scientia Agricultura Sinica. College of Food Engineering and Nutritional Science, Shaanxi Normal University.

Gauche, C., Malagoli, E. D., \& Luiz, M. T. B. (2010). Effect of pH on the Copigmentation of anthocyanins from Cabernet Sauvignon Grape Extracts with Organic Acids. Scientia Agricola, 67(1), 41-46.

Hernani, R. dan Hidayat, T. (2017). "Extraction and Application of Natural Dyes from Secang and Jambal Wood With Several Types of Solvents." Dinamika Kerajinan dan Batik 34(2):113-24.

Kopjar, M. and Piližota, V. (2009). Copigmentation effect of phenolic compounds on red currant juice anthocyanins during storage. Croat. J. Food Sci. Technol 1(2):16-20.

Jacob, S.W., and Toree. J.C.D.L. (2015). Dimethyl Sulfoxide (DMSO) in Trauma and Disease. CRC Press. New York. 
Halaman | 38

Maharani, K. (2003). Stabilitas Pigmen Brazilin Pada Kayu Secang (Caesalpinia Sappan L.). Skripsi Fakultas Teknologi Pertanian, Institut Pertanian Bogor, Bogor.

Mastuti, E., Ester V. K., Merry E. Christanti. (2012). Ektraksi senyawa brazilin dari kayu secang (Caesalpinia sappan L.) Sebagai bahan baku alternatif untuk zat warna alami. Ekuilibrium 11(1): 1-5.

Mekala, K and Radha, R. (2015). A Review on Sappan Wood - A therapeutic Dye Yielding Tree. Research Journal of Pharmacognosy and Phytochemistry 7(4): 227 - 231.

Nirmal, Nilesh P., Mithun S. Rajput, Rangabhatla G. S. V. Prasad, and Mehraj Ahmad. (2015). Brazilin from Caesalpinia Sappan Heartwood and Its Pharmacological Activities: A Review. Asian Pacific Journal of Tropical Medicine 8(6):42130.

Safitri, G.I. (2009). Pengaruh kopigmentasi pewarna alami brazilein kayu secang (Caesalpinia Sappan L.) dengan sinapic acid terhadap stabilitas warna pada model minuman. Skripsi Fakultas Teknologi Pertanian, Institut Pertanian Bogor, Bogor.

Suhartati, T. (2017). Dasar-dasar spektrofotometri UV-Vis dan spektrometri massa untuk penentuan struktur senyawa organik. Aura. Bandar Lampung.
Susanti, I.; Wijaya, H.; Hasanah, F.; and Heryani, S. (2017). Copigmentation of Anthocyanin Extract of Purple Sweet Potatoes (Ipomoea batatas L.) Using Ferulic Acid and Tannic Acid. $3^{\text {rd }}$ International Conference on Tropical and Coastal Region Eco Development 2017.

Wahyuni, H.; Hanum, Tirza; Murhadi. (2017). "Pengaruh Kopigmentasi Terhadap Stabilitas Warna Antosianin Ekstrak Kulit Terung Belanda." Jurnal Teknologi Industri \& Hasil Pertanian 22(1):40-51.

Wissgott, U. and Bortlik, K. (1996). "Prospects for New Natural Food Colorants." Trends in Food Science \& Technology 7(9):298-302.

Yusuf, M.; Shabbir, M., Mohammad, F. (2017). Natural Colorants: Historical, Processing, and Sustainable Prospects. Natural Products and Bioprospect 7: 123 - 145.

Zhang, B.; Yang, S.; Li, N., Zhu, X.; Sheng, W., He, F., Duan, C.; and Han, S. (2017). Colorimetric Study of Malvidin-3-0-Glucoside Copigmented by Phenolic Compounds: The Effect of Molar Ratio, Temperature, $\mathrm{pH}$, and Ethanol Content on color Expression of Red Wine Model Solution. Food Research International 102: 468 - 477. 